\title{
PENGARUH PERILAKU GURU DAN MOTIVASI KERJA TERHADAP KINERJA GURU DI LINGKUNGAN YAYASAN PENDIDIKAN CENDANA PEKANBARU
}

\author{
Afridezi ${ }^{1)}$ \\ Fadly Azhar ${ }^{2)}$ \\ Suarman ${ }^{3)}$ \\ 1) Guru SMA Cendana Pekanbaru \\ 2) Lecturer of Education Management Study Programme PPs University of Riau \\ 3) Lecturer of Education Management Study Programme PPS University of Riau \\ E-Mail: afridezi80@gmail.com
}

\begin{abstract}
This study aims to analyze the effect of independent variables on the dependent variable, it means to analyze how much the influence of teacher behavior and work motivation on teacher performance in The Cendana Education Foundation, Pekanbaru. This study uses a quantitative research method by using a questionnaire as a data collection instrument. The population of this study were 68 teachers in Cendana Education Foundation, Pekanbaru. Then, the sampling technique used was proportional random sampling with a sample size of 59 people. There are two stages data analysis technique that were used, namely: descriptive and inferential analysis. The prerequisite analysis test was carried out, they are the normality test, multicollinearity test, and linearity test. Based on the results of research and data analysis, it can be concluded that first, the teacher behavior has a significant effect on teacher performance at the Cendana Education Foundation. The effect of teacher behavior on teacher performance is $51.5 \%$. Second, the work motivation has a positive and significant effect on teacher performance at the Cendana Education Foundation, that is 43.6\%. Third, the influence of the variable teacher behavior and work motivation together on teacher performance is 61.6\%. Thus, the influence of teacher behavior variables and work motivation on teacher performance is in a moderate interpretation. Teacher performance shows a positive relationship with teacher behavior to improve teacher performance, it is necessary to provide direction. Furthermore, the teacher performance can be improved through supportive, participatory teacher behavior with discipline, and a friendly manner. By giving work motivation to teachers, the foundation should use the right theories of work motivation and taking into account situations and conditions in accordance with school conditions, because the provision of motivation affects the quality of educational services provided by teachers to students, school members and the community.
\end{abstract}

Keywords: Teacher Behavior; Work Motivation; Teacher Performance 


\begin{abstract}
ABSTRAK
Penelitian ini bertujuan untuk menganalisis pengaruh variabel bebas terhadap variabel terikat yaitu seberapa besar Pengaruh Perilaku Guru dan Motivasi Kerja terhadap Kinerja Guru di Lingkungan Yayasan Pendidikan Cendana Pekanbaru. Penelitian ini menggunakan metode penelitian kuantitatif dengan desain survey yang menggunakan angket sebagai alat pengumpul data. Populasi dari penelitian ini adalah guru-guru di lingkungan Yayasan Pendidikan Cendana Pekanbaru yang berjumlah 68 orang. Teknik pengambilan sampel yang digunakan proporsional ramdom sampling dengan jumlah sampel 59 orang.Teknik analisa data yang digunakan ada dua tahap yaitu: analisis deskriptif dan inferensial. Sebelumnya dilakukan uji prasyaratan analisis yaitu uji normalitas, uji multikolinieritas, dan uji linieritas. Berdasarkan hasil penelitian dan pengolahan data dapat disimpulkan bahwa Pertama perilaku guru memiliki pengaruh yang signifikan terhadap kinerja guru di Yayasan Pendidikan Cendana. Besarnya pengaruh antara perilaku guru terhadap kinerja guru sebesar $51,5 \%$. Kedua motivasi kerja memiliki pengaruh yang positif dan signifikan terhadap kinerja guru di Yayasan Pendidikan Cendana. Besarnya pengaruh antara motivasi kerja terhadap kinerja guru sebesar $43,6 \%$. Ketiga Besarnya pengaruh variabel perilaku guru dan motivasi kerja secara bersamasama terhadap kinerja guru adalah sebesar 61,6\%. Dengan demikian, Pengaruh variabel perilaku guru dan motivasi kerja terhadap kinerja guru tersebut berada pada tafsiran sedang. Kinerja guru menunjukkan hubungan positif dengan perilaku guru untuk meningkatkan kinerja guru perlu adanya pemberian arahan. Kinerja guru dapat ditingkatkan melalui perilaku guru yang suportif, partisipatif dilakukan dengan disiplin, pembawaan yang ramah. Pemberian motivasi kerja terhadap guru hendaknya menggunakan teoriteori pemberian motivasi kerja yang tepat dan dengan mempertimbangkan situasi dan kondisi yang sesuai dengan kondisi sekolah, karena pemberian motivasi berpengaruh terhadap kualitas pelayanan pendidikan yang diberikan guru terhadap peserta didik, warga sekolah serta masyarakat.
\end{abstract}

Kata Kunci : Perilaku Guru; Motivasi Kerja; Kinerja Guru

\section{PENDAHULUAN}

Pendidikan adalah suatu sarana untuk mengembangkan dan mentransfer ilmu pengetahuan, karena pendidikan adalah sebuah investasi masa depan bangsa, serta pijakan yang sangat mendasar untuk mencapai kemajuan dan keberhasilan suatu bangsa, karena tanpa adanya pendidikan maka peradapan tidak akan berubah. Pendidikan merupakan proses perubahan sikap dan tata laku seseorang atau kelompok orang dalam usaha mendewasakan manusia melalui upaya pengajaran dan latihan Susanna (2014). Dengan demikian untuk mencapai pendidikan yang di- inginkan maka diperlukan guru yang berkualitas, dalam proses belajar mengajar guru merupakan factor utama yang menentukan keberhasilan pendidikan.

Meskipun demikian, pembangunan pendidikan masih dihadapkan pada sejumlah permasalahan terutama berkaitan dengan tenaga kependidikan pada setiap jenjang dan satuan pendidikan dasar dan menengah, khususnya profesi guru yang menurut banyak orang mengatakan bahwa kinerja dan kemampuan mengajarnya ketersediaan tenaga guru profesional yang menunjang pelaksanaan relatif masih termasuk 
kelompok kategori rendah. Oleh karena itu kerjasama antara pihak sekolah selaku penyelenggara pendidikan dengan stakeholder pendidikan harus dilakukan demi tercapainya tujuan pendidikan.

Menurut Supardi (2016) kinerja guru adalah kemampuan dan keberhasilan guru dalam melaksanakan tugastugas pembelajarannya yang dimulai dari merencanakan pembelajaran sampai kepada guru melakukan penilaian hasil belajar. Kinerja guru dapat dilihat dari proses kerja atau hasil kerja. Suatu pekerjaan selalu mempunyai langkahlangkah (prosedur) kerja prosedur kerja selalu mengarah pada peningkatan hasil pekerjaan yang sesuai dengan tuntutan kerja. Apabila suatu pekerjaan dilakukan sesuai dengan prosedurnya, maka akan sampai pada hasil kerja yang diinginkan. Senada dengan Sukarman, (2018) Kualitas kinerja guru akan sangat menentukan pada kualitas hasil pendidikan, karena guru merupakan pihak yang paling banyak bersentuhan dengan siswa dalam proses pembelajaran di lembaga pendidikan, dengan demikian kinerja guru berkaitan dengan aktifitas dan perilaku kerjanya dalam mengelola pembelajaran.

Berdasarkan fakta dilapangan, adanya kesalahan guru dalam memahami profesinya akan mengakibatkan bergesernya fungsi guru secara perlahan-lahan, yang akan berdampak dalam penurunan kinerja guru dalam mengajar. Hal ini senada dengan penelitian Ika Rahmawati (2015) permasalahan lain masih banyaknya guru yang belum melaksanakan tugas-tugas sekolah secara professional serta kurang menunjukkan kinerja mengajar yang baik, hal ini dipengaruhi oleh suasana lingkungan kerja

Menurut Supardi (2016) salah satu factor yang memperngaruhi kinerja adalah perilaku, dengan demikian dapat diartikan kinerja guru sangat dipengaruhi oleh karakteristik dari guru itu sendiri. Dengan kata lain, kinerja guru dipengaruhi oleh dua faktor, yaitu faktor intern maupun ekstern. Pengaruh intern tersebut dapat berupa kemungkinan guru memiliki masalah dengan keluarga atau memang sedang tidak dalam kondisi yang baik. Pengaruh ekstern dapat berupa bagaimana kondisi lingkungan sekolah, pelaksanaan organisasi sekolah, budaya sekolah, peran kepala sekolah, budaya kerja dan hubungan dengan warga sekolah lainnya.

Dalam mewujudkan keberhasilan peserta didik dimulai dari diri guru itu sendiri, dimana guru harus memiliki perilaku yang belum sesuai dengan tuntutan sebagai seorang pendidik. Standar perilaku pendidik dalam pembelajaran meliputi: kejujuran, keterbukaan, dan demokrasi Silahuddin (2016). Dalam melaksanakan tugas profesi pendidik, perlu ditetapkan kode etik pendidik sebagai pedoman bersikap dan berperilaku dalam bentuk nilai-nilai moral dan etika dalam jabatan sebagai pendidik putera-puteri bangsa. Pedoman sikap dan perilaku yang dimaksud adalah nilai-nilai moral yang membedakan perilaku pendidik yang baik dan perilaku pendidik yang buruk, yang boleh dan yang tidak boleh dilaksanakan selama melaksanakan tugas-tugas profesionalnya untuk mendidik, mengajar, membimbing, mengarahkan, melatih, menilai, dan mengevaluasi peserta didik, serta sikap pergaulan seharihari di dalam dan luar sekolah (Gade, 2015).

Selain perilaku guru yang baik, seorang guru juga harus memiliki motivasi dalam bekerja. Motivasi menurut Sedarmayanti (2010) merupakan kesediaan mengeluarkan tingkat upaya tinggi kearah tujuan organisasi yang dikondisikan oleh kemampuan upaya itu untuk memenuhi kebutuhan individual. 
Perlu tidaknya seorang guru memiliki motivasi kerja dapat dilihat dari suatu kebutuhan yang dipenuhi, seorang guru akan termotivasi untuk menyelesaikan suatu pekerjaan apabila ada kebutuhan yang akan dipenuhi. Motivasi juga ditentukan oleh pengarahan perilaku, seorang guru akan berusaha untuk mengarahkan perilaku yang baik supaya tujuannya tercapai. Jadi motivasi sangat berbanding lurus dengan cita-cita seseorang, jika memiliki cita-cita tinggi maka akan memiliki motivasi untuk meraih cita-cita tersebut akan berbeda dengan guru yang tanpa motivasi atau motivasi rendah. Motivasi sebagai penentu dalam keberhasilan dalam bekerja yang dapat menggambarkan kinerja seorang guru dalam suatu lembaga pendidikan, jika seorang guru memiliki perilaku postif dan motivasi kerja yang tinggi maka kinerja gurunya meningkat.

Dalam pengamatan peneliti di Yayasan Pendidikan Cendana Pekanbaru yang terdiri dari lima unit sekolah secara umum terkait dengan perilaku guru secara akademik maupun non akademik dan motivasi, sudah bagus namun perlu perbaikan ke depannya karena masih ditemukan perilaku dan motivasi kerja guru-guru di Yayasan Pendidikan Cendana yang belum maksimal, hal ini bisa dilihat dari masih ada terdapat guru yang tidak siap dalam perencanaan, pelaksanaan pembelajaran di sekolah serta masih terdapat guru yang kurang disiplin, kurang motivasi dalam bekerja, sehingga menyebabkan rendahnya kinerja guru. Berdasarkan hal tersebut maka peneliti tertarik untuk melakukan penelitian tentang kinerja guru dan kaitannya dengan perilaku guru dan motivasi dengan judul:" Pengaruh Perilaku Guru dan Motivasi Kerja terhadap Kinerja Guru Di Lingkungan Yayasan Pendidikan Cendana Pekanbaru".
Berdasarkan pada latar belakang maka dapat dirumuskan beberapa masalah pada penelitian ini sebagai berikut: 1) Bagaimanakah perilaku guru di lingkungan Yayasan Pendidikan Cendana dilihat dari sisi demografi? 2) Bagaimanakah motivasi kerja di lingkungan Yayasan Pendidikan Cendana dilihat dari sisi demografi?3) Bagaimanakah kinerja guru di lingkungan Yayasan Pendidikan Cendana dilihat dari sisi demografi? 4)Apakah terdapat pengaruh yang signifikan perilaku guru terhadap kinerja guru di lingkungan Yayasan Pendidikan Cendana? 5) Apakah terdapat pengaruh yang signifikan motivasi kerja terhadap kinerja guru di lingkungan Yayasan Pendidikan Cendana? 6) Apakah terdapat pengaruh yang signifikan perilaku guru dan motivasi kerja secara bersama-sama terhadap kinerja guru di lingkungan Yayasan Pendidikan Cendana?

Tujuan penelitian ini adalah sebagai berikut: 1) Untuk menganalisis perilaku guru di lingkungan Yayasan Pendidikan Cendana dari sisi demografi.2) Untuk menganalisis motivasi kerja di lingkungan Yayasan Pendidikan Cendana dari sisi demografi. 3) Untuk menganalisis kinerja guru di lingkungan Yayasan Pendidikan Cendana dari sisi demografi.4) Menganalisis pengaruh yang signifikan perilaku guru terhadap kinerja guru dilingkungan Yayasan Pendidikan Cendana. 5) Menganalisis pengaruh yang signifikan motivasi kerja terhadap kinerja guru dilingkungan Yayasan Pendidikan Cendana. 6) Menganalisis pengaruh yang signifikan perilaku guru dan motivasi kerja terhadap kinerja guru dilingkungan Yayasan Pendidikan Cendana.

\section{KAJIAN TEORITIS}

\section{Kinerja Guru}

Kinerja guru merupakan kemampu-

an dan keberhasilan guru dalam 
melaksanakan tugas- tugas pembelajaran (Supardi, 2014). Pendapat lain Kinerja guru adalah hasil kerja guru yang terefleksi dalam cara merencanakan, melaksanakan dan menilai proses belajar mengajar intensitasnya dilandasi oleh etos kerja, serta disiplin profesional dalam proses pembelajaran (Hamzah B. Uno,2014).

Menurut Sukarman (2018) juga menambahkan kinerja guru adalah seperangkat perilaku nyata yang ditunjukkan guru pada waktu dia memberikan pelajaran kepada siswanya. Sejalan menurut Subroto dalam Sukarman (2018) menyatakan kinerja guru dalam proses mengajar adalah kesanggupan dan kecakapan para guru dalam menciptakan suasana komunikasi yang edukatif antara guru dan peserta didik yang mencakup segi kognitif, afektif dan prisikomotorik sebagai upaya mempelajari sesuatu berdasarkan perencanaan sampai dengan tahap evaluasi dan tindak lanjut agar tercapai tujuan pengajaran.

Kinerja guru dapat diartikan sebagai suatu kondisi yang menunjukkan kemampuan seorang guru dalam menjalankan tugasnya di sekolah serta menggambarkan adanya suatu perbuatan yang ditampilkan guru dalam atau selama melakukan aktivitas pembelajaran. Upaya-upaya untuk meningkatkn kinerja guru di sekolah adalah suatu tuntutan yang harus dipenuhi oleh setiap insan pendidik

\section{Perilaku Guru}

Perilaku yang baik sangat diperlukan dalam menyelesaikan suatu pekerjaan guna untuk mencapai hasil yang terbaik. Perilaku pada hakekatnya adalah segenap manifestasi hayati individu dalam berinteraksi dengan lingkungan, mulai dari perilaku yang paling nampak sampai yang tidak tampak, dari yang dirasakan sampai paling yang tidak dirasakan (Okviana, 2019).

Perilaku yang diperlihatkan oleh individu bukan sesuatu yang dilakukan sendiri, tetapi selalu dalam interaksinya dengan lingkungan Nana Syaodih (2003: 46). Hamalik dalam Apuanor (2017) Perilaku guru merupakan tingkat afeksi yang positif dan negative meliputi mendidik, mengajar, membimbing, mengarahkan, melatih, menilai dan mengevaluasi yang dihubungkan dengan objek psikologis yaitu peserta didik di sekolah.

\section{Motivasi kerja}

Motivasi kerja adalah salah satu faktor yang menentukan kinerja seseorang. Besar kecilnya pengaruh motivasi pada kinerja seseorang tergantung pada seberapa banyak intensitas motivasi yang diberikan. Perbedaan motivasi kerja bagi seorang guru biasanya tercermin dalam berbagai kegiatan dan bahkan prestasi yang dicapai (Hamzah B.Uno, 2017). Hal senada diungkapkan Harbani (2010), motivasi kerja adalah pemberian dorongan atau sesuatu yang melatarbelakangi seseorang untuk melakukan sesuatu atau tingkah laku. Kemudian diperkuat Asa'ad (dalam, Harbani 2010), motivasi kerja adalah sesuatu yang menimbulkan semangat atau dorongan kerja.

Motivasi (dorongan) sebagai salah satu strategi yang digunakan untuk meningkatkan kinerja guru, karena efektifitas kelancaran pekerjaan guru tergantung pada motivasi. Kinerja seorang guru ditentukan oleh diri mereka sendiri, motivasi merupakan hal yang terpenting bagi dirinya untuk bisa bertahan di tempat bekerja.

\section{METODOLOGI PENELITIAN}

Penelitian ini menggunakan penelitian kuantitatif dengan variabel 
bebas perilaku guru dan motivasi kerja terhadap kinerja guru. Penelitian yang dilakukan untuk menganalisis pengaruh variabel bebas terhadap variabel terikat. Dalam penelitian ini bertujuan untuk mencari pengaruh variabel independen (bebas) terhadap variabel dependen (terikat) yaitu pengaruh antara perilaku guru $\left(\mathrm{X}_{1}\right)$ dan motivsi kerja $\left(\mathrm{X}_{2}\right)$ dengan kinerja guru (Y). Dalam penelitian ini data dan informasi dikumpulkan dari responden dengan menggunakan kuesioner/angket. Populasi penelitian ini seluruh guru di lingkungan Yayasan Pendidikan Cendana Pekanbaru yang berjumlah 68. Untuk menentukan jumlah sampel digunakan rumus Slovin sehingga diperoleh 59 orang, dengan teknik proportional random sampling. Adapun analisis data yang digunakan adalah analisis statistik deskriptif dan analisis statistik inferensial. Pengujian hipotesis dengan analisis regresi linier sederhana dan regresi linier berganda, terlebih dahulu dilakukan uji persyaratan analisis, yaitu uji normalitas, uji multikolinieritas dan uji linieritas.

\section{HASIL PENELITIAN DAN PEM- BAHASAN}

1. Deskripsi Data Penelitian Dalam penelitian ini menggunakan 3 (tiga) variabel, yaitu variabel Kinerja Guru (Y), Perilaku Guru $\left(\mathrm{X}_{1}\right)$, dan Motivasi Kerja $\left(\mathrm{X}_{2}\right)$. Selanjutnya untuk pendeskripsian data ini, secara singkat akan berdasarkan Skor Mean. Berikut ini akan diuraikan perhitungan deskripsi masing-masing variabel:

a. Variabel Kinerja Guru

Dilihat dari Sisi Demografi
Pada variabel kinerja guru dilihat dari sisi gender perempuan (rerata mean $=4,19$ ) lebih tinggi tingkat kinerja gurunya dibandingkan dengan laki-laki (rerata mean $=4,11$ ). Ini diakibatkan oleh perempuan menjalani peran ganda, akibatnya banyak guru perempuan yang pekerjaannya dibantu oleh guru laki-laki. Dan variabel kinerja guru dilihat dari sisi usia bertugas, guru yang berusia 5160 tahun rata-rata sebesar 4,38 bila dibandingkan dengan guru yang berusia 31-40 sebesar 4,13. Dan 21-30 tahun sebesar 4,03. Hal ini diakibatkan oleh guru yang berusia 51-60 tahun dan masa kerjanya yang lebih lama (21-30) tahun, lebih banyak mendapatkan tugas dan tanggung jawab disekolah. Secara keseluruhan bahwa kinerja guru dilihat dari skor mean dan secara demografi, berada dalam tafsiran tinggi.

b. Variabel Perilaku Guru (X1) Dilihat dari Sisi Demografi Pada variabel perilaku guru dilihat dari sisi gender, secara umum guru perempuan memiliki perilaku guru yang lebih baik dari pada guru laki-laki, hal ini ditandai dengan nilai rata-rata 4,47 berbanding 4,42. Hal ini disebabkan karena secara kodratnya perempuan memiliki perilaku yang baik lebih menjiwai profesi sebagai seorang guru, dalam menjalankan tugas dapat bekerjasama, 
memiliki komunikasi yang baik dengan siswa antara guru juga dengan orang tua murid, serta memiliki sikap yang lebih patuh terhadap peraturan sekolah. Sementara itu, dilihat dari sisi usia dan masa kerja, guru yang berusia 31-40 tahun dan masa kerja 1-10 tahun memiliki perilaku yang paling rendah dengan nilai rata-rata (skor mean) sebesar 4,21 dan 4,37. Meskipun kelompok umur 5160 tahun serta masa kerja 21-30 tahun memiliki perilaku yang tinggi yaitu berada pada skor mean 4,65 dan 4,58. Hal ini menandakan tingkat perilaku yang terjadi pada guru berada pada level yang sangat tinggi. Tidak bisa dipungkiri bahwa guru yang lebih berpengalaman memiliki perilaku yang bagus dan dapat menjadi teladan terhadap guru yang memiliki masa kerja yang masih sedikit dikarenakan belum memiliki pengalaman yang banyak.

c. Variabel Motivasi Kerja (X2) Dilihat dari Sisi Demografi Variabel motivasi kerja dilihat dari sisi gender, secara statistik guru perempuan memiliki motivasi kerja yang lebih tinggi dari pada guru laki-laki hal ini ditandai dengan nilai rata-rata 4,05 berbanding 3,85. Hal ini

\section{Uji t Hitung Koefisien antara Perilaku Guru (X1) terhadap Kinerja Guru}

(Y) bisa diakibatkan karena profesi guru lebih cocok dijalankan oleh seorang perempuan, dalam kenyataannya secara umum profesi guru banyak perempuan. Selain itu perempuan memilih profesi guru karena dapat membantu ekonomi keluarga, seorang guru perempuan mampu berbuat lebih dalam rangka untuk membantu kehidupan rumah tangganya. Sementara itu, jika dilihat dari sisi usia dan masa kerja, guru yang berusia 51-60 sebesar 4,17 dan guru berusia 41-50 sebesar 4,03 tahun memiliki motivasi yang lebih tinggi dibandingkan dengan guru yang berusia 31-40 tahun sebesar 3,88 dan 21-30 tahun sebesar 3,75. Hal ini diakibatkan oleh guru yang berusia 41-60 tahun dan masa kerja yang lebih lama (21-30) tahun, lebih banyak mendapatkan peran dan tanggung jawab disekolah.

2. Pengujian Hipotesis terhadap Kinerja Guru (Y)

Hipotesis pertama yang akan di uji adalah terdapat pengaruh positif dan signifikan antara perilaku guru $\left(\mathrm{X}_{1}\right)$ terhadap kinerja guru (Y) Yayasan Pendidikan Cendana Pekanbaru. a. Pengaruh Perilaku Guru $\left(\mathrm{X}_{1}\right)$ 


\begin{tabular}{|l|r|r|r|}
\hline Konstanta & 21,444 & 2,019 & 0,048 \\
\hline Perilaku Guru & 0,806 & 7,786 & 0,000 \\
\hline
\end{tabular}

Pada uji regresi linier sederhana dimana hasil persamaan regresi yang dihasilkan, koefisien variabel perilaku guru (X1) terhadap kinerja guru (Y), diperoleh nilai konstanta (a) $=21,444$ dan $b=0,806$, sehingga persamaan regresinya menjadi $\hat{Y}=21,444+0,806 X_{1}$, dan dari persamaan regresi dinyatakan bahwa hubungan kedua variabel tersebut adalah signifikan dan linier. Berdasarkan tabel di atas, koefisien Variabel perilaku guru memiliki nilai thitung $=7,786$ dengan probabilitas sig $=0,000$.
Besarnya nilai $t$ tabel dengan $n=59$, variabel $\mathrm{k}=2, \quad \mathrm{df}=\mathrm{n}-\mathrm{k}, \quad$ diperoleh ttabel $=2,00$. Sehingga thitung $>$ ttabel dan nilai sig $0,000<0,05$. Dengan demikian dapat disimpulkan bahwa perilaku guru $\left(\mathrm{X}_{1}\right)$ berpengaruh secara signifikan terhadap kinerja guru (Y). Berdasarkan uraian tersebut maka hipotesis pertama yang menyatakan terdapat pengaruh yang signifikan antara perilaku guru $\left(\mathrm{X}_{1}\right)$ terhadap kinerja guru (Y) diterima.

\section{Pengaruh Variabel Perilaku Guru (X1) terhadap Kinerja Guru (Y)}

\begin{tabular}{|c|c|c|}
\hline \multicolumn{1}{|c|}{ Predictor } & R & R Square \\
\hline Konstanta \& Perilaku Guru & 0,718 & 0,515 \\
\hline
\end{tabular}

Pada tabel diperoleh nilai R Square (r2) sebesar 0,515, dengan demikian pengaruh perilaku guru terhadap kinerja guru adalah sebesar, $K D=r^{2} \times 100 \%$, $0,515^{2} \times 100 \%=51,5 \%$. Sedangkan sisanya $48,5 \%$ ditentukan oleh variabel lain yang tidak dapat dijelaskan dalam penelitian ini. Dengan demikian, maka besarnya pengaruh variabel perilaku guru $\left(\mathrm{X}_{1}\right)$ terhadap kinerja guru $(\mathrm{Y})$ berada pada level sedang.

\section{b. Pengaruh Motivasi Kerja $\left(\mathbf{X}_{2}\right)$ terhadap Kinerja Guru (Y)}

Hipotesis kedua yang akan di uji adalah terdapat pengaruh positif dan signifikan antara motivasi kerja $\left(\mathrm{X}_{2}\right)$ terhadap kinerja guru (Y) Yayasan Pendidikan Cendana Pekanbaru. 
Uji t Hitung Koefisien antara Motivasi Kerja (X2) terhadap Kinerja Guru

(Y)

\begin{tabular}{|l|r|r|r|}
\hline \multirow{2}{*}{ Model } & $\begin{array}{r}\text { Unstandardized } \\
\text { Coefficients }\end{array}$ & \multirow{2}{*}{ t } & Sig \\
\cline { 1 - 2 } & B & & \\
\hline Konstanta & 43,684 & 4,790 & 0,000 \\
\hline Motivasi Kerja & 0,600 & 6,634 & 0,000 \\
\hline
\end{tabular}

Dependent Variabel: Kinerja Guru

Berdasarkan tabel tentang koefisien variabel motivasi kerja $\left(\mathrm{X}_{2}\right)$ terhadap kinerja guru (Y), diperoleh nilai konstanta (a) $=43,684$ dan $b=0,600$, sehingga persamaan regresinya menjadi $\hat{Y}=43,684+0,600 X_{2}$, dan dari persamaan regresi tersebut dapat dinyatakan bahwa hubungan kedua variabel tersebut adalah signifikan dan linier. Berdasarkan tabel di atas, koefisien Variabel motivasi kerja memiliki nilai thitung $=6,634$ dengan probabilitas sig $=$

Pengaruh Variabel Motivasi Kerja $\left(\mathbf{X}_{2}\right)$ terhadap Kinerja Guru (Y)

\begin{tabular}{|r|c|c|}
\hline \multicolumn{1}{|c|}{ Predictor } & R & R Square \\
\hline Konstanta \& Motivasi Kerja & 0,660 & 0,436 \\
\hline
\end{tabular}

Pada tabel diatas diperoleh nilai $\mathrm{R}$ Square $\left(\mathrm{R}^{2}\right)$ sebesar 0,436, dengan demikian pengaruh motivasi kerja terhadap kinerja guru adalah sebesar $K D=r^{2} \times 100 \%$, $0,436^{2} \times 100 \%=43,6 \%$. Sedangkan sisanya $56,4 \%$ ditentukan oleh variabel
0,000 . Besarnya nilai t-tabel dengan $\mathrm{n}=59$, variabel $\mathrm{k}=2, \mathrm{df}=\mathrm{n}-\mathrm{k}$, diperoleh $\mathrm{t}$-tabel=2,00. Sehingga t-hitung $>\mathrm{t}$-tabel dan nilai sig $0,000<0,05$. Dengan demikian dapat disimpulkan bahwa motivasi kerja $\left(\mathrm{X}_{2}\right)$ berpengaruh secara signifikan terhadap kinerja guru (Y). Berdasarkan uraian tersebut maka hipotesis kedua yang berbunyi terdapat pengaruh yang signifikan antara motivasi kerja $\left(\mathrm{X}_{2}\right)$ terhadap kinerja guru (Y) diterima. lain yang tidak dapat dijelaskan dalam penelitian ini. Dengan demikian, maka besarnya pengaruh variabel motivasi kerja $\left(\mathrm{X}_{2}\right)$ terhadap kinerja guru $(\mathrm{Y})$ berada pada level sedang 


\section{c. Pengaruh Perilaku Guru $\left(\mathbf{X}_{1}\right)$ dan Motivasi Kerja $\left(\mathbf{X}_{2}\right)$ terhadap Kinerja Guru (Y)}

Hipotesis ketiga yang disajikan adalah terdapat pengaruh yang signifikan antara perilaku guru $\left(\mathrm{X}_{1}\right)$ dan motivasi kerja $\left(\mathrm{X}_{2}\right)$ terhadap kinerja guru $(\mathrm{Y})$.

Tabel Uji t Hitung Koefisien antara Perilaku Guru $\left(\mathrm{X}_{1}\right)$ dan Motivasi Kerja $\left(\mathrm{X}_{2}\right)$ terhadap Kinerja Guru (Y)

\begin{tabular}{|l|r|r|c|}
\hline \multirow{2}{*}{ Model } & $\begin{array}{c}\text { Unstandardized } \\
\text { Coefficients }\end{array}$ & \multirow{2}{*}{ t } & \multirow{2}{*}{ Sig } \\
\cline { 2 - 2 } & \multicolumn{1}{|c|}{ B } & & \\
\hline Konstanta & 10,775 & 1,084 & 0,283 \\
\hline Perilaku Guru & 0,571 & 5,130 & 0,000 \\
\hline Motivasi Kerja & 0,346 & 3,833 & 0,000 \\
\hline
\end{tabular}

Berdasarkan tabel diatas tentang koefisien variabel perilaku guru $\left(\mathrm{X}_{1}\right)$ dan motivasi kerja $\left(\mathrm{X}_{2}\right)$ terhadap kinerja guru (Y), diperoleh nilai konstanta (a)=10,775, $b_{1}=0,571$, dan $b_{2}=0,346$ sehingga persamaan regresinya menjadi $\hat{Y}=10,775+0,571 X_{1}+0,346 X_{2}$. Makna dari persamaan regresi di atas adalah: besarnya nilai konstanta (a) sebesar 10,775 artinya, jika kadar perilaku guru dan motivasi kerja guru sama dengan nol, maka nilai kinerja guru yang dapat dipertahankan adalah sebesar 10,775.
Koefisien regresi motivasi kerja (b1) sebesar 0,571 artinya, bahwa setiap ada kenaikan satu satuan dari perilaku guru, maka akan diikuti dengan peningkatan kinerja guru sebesar 0,571 satuan dengan asumsi variabel perilaku guru tetap. Koefisien regresi motivasi kerja (b2) sebesar 0,346 artinya, bahwa setiap ada kenaikan satu satuan dari motivasi kerja, maka akan diikuti dengan penurunan kinerja guru sebesar 0,346 satuan dengan asumsi variabel motivasi kerja tetap.

\section{Uji F Hitung Koefisien antara Perilaku Guru $\left(\mathbf{X}_{1}\right)$ dan Motivasi Kerja $\left(\mathbf{X}_{2}\right)$} terhadap Kinerja Guru (Y)

\begin{tabular}{|c|c|c|}
\hline Model & $\mathbf{F}$ & Sig \\
\hline Regresi & 44,939 & 0,000 \\
\hline
\end{tabular}

Independent Variabel: Motivasi Kerja, Perilaku Guru

Dependent Variabel: Kinerja Guru

Berdasarkan tabel di atas, diketahui nilai F-hitung sebesar 44,939 dengan nilai signifikan $=0,000$. Besarnya nilai F-tabel dengan $\mathrm{n}=59$, variabel $\mathrm{k}=3, \mathrm{df} 1=\mathrm{k}-1, \mathrm{df} 2=\mathrm{n}-\mathrm{k}$ diperoleh Ftabel=3,19. Sehingga F-hitung $>$ F-tabel dan nilai sig $0,000<0,05$. Dengan demikian dapat disimpulkan bahwa perilaku guru $\left(\mathrm{X}_{1}\right)$ dan motivasi kerja $\left(\mathrm{X}_{2}\right)$ secara bersama-sama berpengaruh secara signifikan terhadap kinerja guru (Y). Sehingga dapat disimpulkan bahwa hipotesis ketiga yang berbunyi terdapat pengaruh yang signifikan antara perilaku guru $\left(\mathrm{X}_{1}\right)$ dan motivasi kerja $\left(\mathrm{X}_{2}\right)$ terhadap kinerja guru (Y) diterima. 


\section{Pengaruh Variabel Perilaku Guru $\left(\mathbf{X}_{1}\right)$ dan Motivasi Kerja $\left(\mathbf{X}_{2}\right)$ terhadap Kinerja Guru (Y)}

\begin{tabular}{|c|c|c|}
\hline Predictor & R & R Square \\
\hline Konstanta, Motivasi Kerja dan Perilaku Guru & 0,785 & 0,616 \\
\hline
\end{tabular}

Pada tabel diperoleh nilai $\mathrm{R}$ Square $\left(\mathrm{R}^{2}\right)$ sebesar 0,616, dengan demikian pengaruh perilaku guru dan motivasi kerja terhadap motivasi kinerja guru adalah sebesar $K D=r^{2} \times 100 \%$, $0,616 \times 100 \%=61,6 \%$. Sedangkan sisanya $36,5 \%$ ditentukan oleh variabel lain yang tidak dapat dijelaskan dalam penelitian ini. Dengan demikian, maka besarnya pengaruh variabel perilaku guru $\left(\mathrm{X}_{1}\right)$ dan motivasi kerja $\left(\mathrm{X}_{2}\right)$ terhadap kinerja guru (Y) berada pada level sedang.

\section{SIMPULAN}

Berdasarkan rumusan masalah, hipotesis yang diajukan serta hasil penelitian

dan pembahasan, maka kesimpulan dalam penelitian ini adalah:

1. Variabel perilaku guru memiliki pengaruh yang signifikan terhadap kinerja guru di Yayasan Pendidikan Cendana. Besarnya pengaruh antara perilaku guru terhadap kinerja guru sebesar $51,5 \%$. Pengaruh variabel perilaku guru terhadap kinerja guru tersebut berada pada tafsiran sedang.

2. Variabel motivasi kerja memiliki pengaruh yang positif dan signifikan terhadap kinerja guru di Yayasan Pendidikan Cendana. Besarnya pengaruh antara motivasi kerja terhadap kinerja guru sebesar 43,6\%. Pengaruh variabel motivasi kerja terhadap kinerja guru tersebut berada pada tafsiran sedang.

3. Variabel perilaku guru dan motivasi kerja secara bersama-sama memiliki pengaruh yang signifikan terhadap kinerja guru di Yayasan Pendidikan Cendana. Pengaruh antarvariabel ini secara bersama-sama memberikan korelasi sebesar 0,785 dengan kinerja guru. Besarnya pengaruh variabel perilaku guru dan motivasi kerja secara bersama-sama terhadap kinerja guru adalah sebesar 61,6\%. Dengan demikian, Pengaruh variabel perilaku guru dan motivasi kerja terhadap kinerja guru tersebut berada pada tafsiran sedang.

\section{UCAPAN TERIMA KASIH}

Pada akhirnya, penulis menyadari bahwa artikel ini tidak akan selesai tanpa dukungan dari rekan-rekan majelis guru SMA Cendana Pekanbaru atas segala bantuan dan dukungan yang telah diberikan.

\section{DAFTAR PUSTAKA}

Apuanor, Mulyana Ningsih, Sudarmono, 2017. Sikap Guru Pemicu Munculnya Perilaku Negatif Siswa. Jurnal Paedagogie Vol V Nomor 1 ISSN 26564580 
Gade, S. 2015. Kode Etik Pendidik Menurut Ibnu Jama'ah. Jurnal Pencerahan, 9(1), 23-36.

Hamzah B. Uno. 2017. Teori Motivasi dan Pengukurannya, Bumi Aksara, Jakarta.

Hamzah B. Uno, Nina Lamatenggo. 2014, Teori Kinerja dan Pengukurannya, Bumi Aksara, Jakarta.

Harbani, 2010, Kepemimpinan Birokrasi, Alfabeta, Bandung.

Ika Rahmawati, 2015. Pengaruh Iklim Sekolah dan Motivasi Kerja Terhadap Kinerja Mengajar Guru SMK di Kota Bandung, Jurnal Universitas Pendidikan Indonesia.

Nana Syaodih. 2010. Metode Penelitian Pendidikan, Remaja Rosdakarya, Bandung.N.E. Rohmawati, 2017. Pengaruh Iklim Organisasi Sekolah Dan Motivasi Kerja Guru Terhadap Kinerja Guru (Studi di SD Negeri Kecamatan Ciamis), Jurnal Ilmiah Pascasarjana Administrasi Pendidikan Vol 5 No 1, Universitas Galuh.
Oktaviana, 2019. Pengembangan Media Big Book untuk Meningkatkan Perilaku Moral Pada Anak. Jurnal Pendidikan dan Pemberdayaan Masyarakat, ISSN 2477-2992, Universitas Negeri Yogyakarta.

Sedarmayanti, 2010. SDM dan Produktivitas Kerja. Mandar Maju, Bandung.

Silahuddin. 2016. Media Teknologi dan Implikasinya Dalam Pengembangan Pendidikan. Jurnal Circuit, 2(1), 199-207.

Susanna. 2014. Kepribadian Guru PAI dan Tantangan Globalisasi. Jurnal Mudarrisuna, 4(2).

Supardi, 2016. Kinerja guru. PT Raja Grafindo Persada, Jakarta.

Sukarman, 2018. Pengembangan Model Kinerja Berdasarkan Faktor Penentu Kinerja Guru SMP Negeri Di Kecamatan Medan Kota, Jurnal Administrasi dan Manajemen, Universitas Medan. 